\title{
The Implementation of Doctrine of Diversity as an Attempt to Prevent Terrorism in College
}

\author{
Abdul Wahid*1 Sunardi $^{1} \quad$ Dwi Ari Kurniawati ${ }^{2}$ \\ 1.Faculty of Law, University of Islam Malang \\ 2.Faculty of Islamic Studies, University of Islam Malang
}

\begin{abstract}
Terrorism is identified as an extraordinary crime. The specialty of terrorism is caused by the success of cadre recruitment pattern or the seedling process in order to run the organization. There will be always new young cadres who are able to be invited to join the organization. A proverb saying "whatever broken will grow back, whatever lost will be replaced" is the justification that terrorism has become a prohibited organization which obtains the appreciation and "approval" from half of the society. This condition cannot be tolerated to develop. There should be a continuing attempt from several aspects in order to intercept or prevent it, especially from college. One of the attempts which might be undertaken by Muslims is to apply the doctrine or jurisprudence of diversity. This doctrine has the substance which is able to provide effects towards the construction of adherents of religion understanding to not get lost in the path of terrorism.
\end{abstract}

Keywords: doctrine of diversity, terrorism, Islam, college

DOI: $10.7176 / J L P G / 86-15$

Publication date:June $30^{\text {th }} 2019$

\section{Introduction}

If there happens to be some achievements from the subjects of nation, especially the state pillars, people have to appreciate them. Appreciation must also be given to Indonesian National Police which has successfully dismantled the network of terrorism. Special Detachment (Densus) 88 Anti-Terror has frequently dismantled the network of terrorism. However, ironically it was found children and teenagers surrounding the crime scene (TKP) or in the circle of terrorists or this network of radicalism.

As a case example, Densus 88 found and captured several people who were suspected to be the members of terrorists' network in Sukoharjo and Klaten, Central Java. From the capture, surprisingly there were 8 people who were suspected to be the terrorists and they were only teenagers who just graduated from junior high schools and senior high schools.

The teenagers or children found in the crime scene indicate that there has been an involvement of a number of children and teenagers in the network of terrorism and it is an apprehensive reality. Some of the children have been successfully situated and arranged to become the "machines" of terrorism organization.

As the justification of the tragedy, there are several testimonies saying: a number of parents are deeply broken down or surprised to find out that their children are suspected to be terrorists or the suspects of bombing. These parents cannot believe that their children are involved in terrorism because according to them, their children are known to be silent and shy so that they are not certain that their children are involved in terrorism. After the capture undertaken by Densus 88, these parents are wondering why their children have become terrorists.

Saud Usman Nasution from National Agency for Combating Terrorism (BNPT) states that youths are nowadays vulnerable to radical doctrines. Youths are involved in the actions of terrorism namely Bali I bombing, Bali II bombing, Ritz Carlton bombing, JW Marriot, and Australian embassy bombing. Even worse, these days these radical youths not only operate in domestic. They also operate their terror to the international world globally. These youths' ages range from 18-25 years old. This nation generation is trapped by gentle persuasion and becomes the troublemaker in other countries. Youths still factually have the potential to be affected by the group of terrorists' radicalism. ${ }^{1}$

Along with the dismantling case of terrorist network frequently undergone by Densus 88, Russia also experienced violence tragedy because of spectacular terrorist attack. At least 30 people were dead and dozens were injured because of suicide bombing. Strongly suspected, this attack made use of some children as the perpetrators.

From the above case, people and this nation are "reminded" (challenged) by the strength of terrorist network that we have to always read its development. According to a criminologist and an expert on criminal law Romli Atmasasmita, ${ }^{2}$ the development of international crime especially in the 21 century has increased. It

\footnotetext{
${ }^{1}$ http://nasional.tempo.co/read/news/2015/10/27/063713575/bnpt-cemas-banyak-anak-muda-indonesia-direkrut-jadi-teroris

${ }^{2}$ Romli Atmasasmita, dkk, State Terrorism dalam Perspektif Hukum, Hak Asasi Manusia, dan Agama, Lembaga Penerbitan Fakultas Hukum Unisma, 2003. pp.7.
} 
indicates that we must always be smart in being aware of the condition of the future generations which will not only be the determination of the state future but also ironically be the potential generation that will destroy this country if they are involved in becoming terrorists.

\section{Discussion}

\subsection{Global Fear towards Terrorism}

Terrorists are proven to be able to shake the world from time to time. Terrorists are also indicated as one of globalization diseases which is feared. A stigma as a disease which threatens the world is at least predictable, that one day after the WTC building bombing on September 12, 2001, United Nation Security Council (DKPBB) issued resolution Number 1368 stated that terrorism criminal act is a threat to international peace and security. ${ }^{1}$

Attitude of fear shown by DKPBB is also predictable from its invitation through resolution Number 1373

which obligates all country members of United Nations to partake in the attempts to:

1. Combat terrorism.

2. Bring the perpetrator of terrorism to trial.

3. Review national criminal law if required.

4. Improve the security at the borderline.

5. Control the trade of firearms and explosives.

6. Take immediate actions to prevent and suppress both active and passive activities supporting terrorism especially through Resolution 1337, Resolution 1390, and Resolution 1455.

7. Ratify all relevant United Nation conventions especially Convection 1999 related to Freezing the Finance of Terrorism Perpetrators.

8. Put into trial those who finance, plan, support, protect, and participate in terrorism.

9. Improve cooperation with United Nation Security Council. ${ }^{2}$

Policies issued by United Nation for the global society show that terrorism has become "world's nightmare" which demands all nation subjects to formulate or construct the appropriate steps to fight against it or to cope with it. It cannot be neglected because the action of neglecting is identical with giving chances or spaces for liberalism to grow and develop.

The President of Republic of Indonesia Joko Widodo's attitude towards the act of violence situated by the terrorists is to remind Indonesia's citizens to not be afraid of the terrorists and to prohibit people underestimate them. If people underestimate them, it means that they give them "space". This President's invitation is acceptable even though psychologically it could not be denied by anyone that the action run by terrorists is frightening, especially when the actions turn anyone in the targeted location to become massive victims and dehumanization.

When he was still the candidate of the President of the United States of America, Donald Trump through his campaign team stated his promises that if elected to become the President of the United States of America, there would be policies regarding torture towards the suspect of terrorists. The attitude of Donald Trump also indicated that Trump showed his political attitudes to fight against terrorists by defeating his own fear.

World society fear towards terrorism is reasonable since terrorism is included in the network of criminal organization which is successful in polishing its existence and dynamic with militant cadres. Location mapping followed by real radical actions in several places proves that terrorists are able to intellectualize their movement with the support of their cadres, especially cadres formed as a "machine" to create horrors everywhere.

This shows that terrorist is not stagnant and will never die. Terrorist will always live and thrive along with the development of the society and country. Terrorist always becomes the reflection of the real life pattern of a nation. If the society gives opportunity or tolerance to the growth or development of fundamentalism and radicalism then terrorism will follow because terrorism is identical with organization which favors violence in actualizing its mission.

If terrorists lived in an arid land, then they (terrorists) would difficultly live, be dynamic, and progress themselves. However, if they live in a fruitful or conducive area, then they will quickly grow. This particular condition according to Hendropriyono is the type of society contaminated by the fathom of extreme fundamentalism or religion radicalism. ${ }^{3}$

Those terrorists have various ways to actualize their missions. When one of their modus operandi is thwarted by the agency, they will create and modernize another modus operandi. They will not give up to actualize their radical movement although they have to sacrifice either their lives or other people's.

Exchange in modus operandi also shows that they involved in the terrorist network are considered as a group of people who continuously learn to construct the movement mission and strategy. Robbing, for example,

\footnotetext{
${ }^{1}$ Prepared by the United Nations Office on Drugs and Crime, Legislative Guide to the Universal Anti-Terrorism Conventions and Protocols, United Nations, New York, 2004, pp.1.

${ }^{2}$ Eric Rosand, The Counter Terrorism Committee and the Fight against Terrorism, American Journal International, 2003, pp.97.

${ }^{3}$ A.M. Hendroprioyono, Terorisme: Fundamentalis Kristen, Yahudi dan Islam, (Jakarta: Buku Kompas, 2009), pp.13.
} 
is a type of crime which generates a lot of money, which by public is only assumed as the modus operandi of conventional criminals, whereas this is used as one step to collect funding by terrorists in the name of "funding of jihad."

Responding to the dynamic of modus operandi or steps taken by terrorists, it is logical that many world society subjects react to them. DKPBB, for example, founded Anti-Terrorism Committee which accommodates reports from member countries regarding the attempts which have been undertaken to handle criminal act of terrorism. Reports which are referred to are related to: 1) inventory of regulations which could be implemented, 2) law enforcement, 3) law adjustment. 4) extradition, 5) finance asset control, 6) customs, 7) immigration, 8) illegal firearms trade. ${ }^{1}$

The formation of committee by DKPBB is only one of the ways to show that the development of terrorists' steps in being dynamic or running their organization must be predicted and prepared for ways to be handled, both preventively and repressively. Terrorists will never stop formulating ideas, forming strategies, and developing their organization.

For Indonesia, terrorism is an old-school problem. Although many evaluated that Indonesia has suffered from the threat of terrorism since the beginning of 2000s, terrors in the form of threats towards the sovereignty of the Unitary State of the Republic of Indonesia (NKRI) and the legitimate government have been started since the beginning of its independence. Those threats appeared in many kinds of rebellions and separatist movements.

For comparative reflection materials, it might be that security agencies or Special Detachment 88 never estimate that Jakarta, which is the center of government and state security, is examined brutally by terrorists. A group of terrorists once have been able to make Jakarta horrific because of several bombings they have exploded.

\subsection{How to Become A Terrorist}

Students must agree that no child (a student), including a college student, was born a terrorist. Some of them become terrorists because there have been other parties create or teach them. In this sector, learning how to become a terrorist is a part of existence process and the continuation of terrorism.

A well-known criminologist, Edward Sutherland, who constructed the theory of "crime study" reminds the society that crime or deviating behavior happening in the middle of society is not caused by heredity or genetic factors but it is affected by the intelligence of someone or a group of people in facing incidents, conditions, and society behaviors, or any other aspects as objects to study.

The sector of that "crime study" can run successfully if the subjects of study actually give the opportunity to be formed in becoming radical or a terrorist so that this process is identical with succeeding the process of terrorism learning.

This makes Sutherland has different opinion with conventional criminologists which state that crime in the society is not related to poverty problems or economical empower less. Serious crime including terrorism is one actualization of the success of "criminality learning" so that when a person decides to become a terrorist, it means that he or she has gone through a forming process in line with the doctrines or terrorism-based "curriculum".

Students or college students are recruited to be terrorists because they are productive seedlings who are able to maintain the continuation and militancy of organization. The condition of age and strong power become huge potential which could be utilized, at least to run their important missions.

They are taught to shift their way of thinking and behaving in relation with the country. When people change the construction of a country through a khilafah system or fathom, this system or fathom will be considered the most correct doctrine which fulfills the construction of Islamic State. Then, the transformation of doctrine and learning could be categorized as a terroristic-based teaching.

Khalilul Umar reminded that all nation subjects and global society must not underestimate neatly networked crimes and crimes run by a group of intelligent and exclusive people, including those whose cadre recruitment run progressively. ${ }^{2}$ It shows that terrorism is a "covert organization" or an illegal community which accepts or is accepted (recognized) by a particular community element, which inside is full of or run by skilled people. Thus, it is reasonable that many interpret or rationalize terrorists successful in forming recruits everywhere or in forming their cadres through "criminality learning" especially to prove their identity and existence, through the aspects of doctrine and ideology.

A psychologist Sarlito Wirawan (2010) has conducted a research towards 44 prisoners of terrorist's case which stated that ideology in which they (terrorists) follow is considered "fixed price". This principle is typically adhered by upper class prisoners during their movement activities. One of the adherents of this "madzhab" is Abu Dujana and his group. ${ }^{3}$

\footnotetext{
${ }^{1}$ Nicholas Rostow, Before and After: The Changed UN Response to Terrorism Since September $11^{\text {th }}$, Cornel International Law Journal, 2002, pp.35.

${ }^{2}$ Khalilul Umar, Surat Dari teroris, LPPT-Indonesia-Global, Jakarta, 2012, pp.3.

${ }^{3}$ Haedar Mustofa, Dinamika Terorisme di Era Globalisasi, Lembaga Kajian Strategis Kebangsaan, 15 May 2016 , Surabaya, pp.4.
} 
That finding could remind all nation subjects, especially the agency and education administrators regarding the local dynamic mapping and global direction or someone's condition or a group of terrorists and terrorist candidates, that terrorists' way of thinking and behaving are to believe or even defend and maintain, though it is completed through risking lives.

One becomes a terrorist not only to be trained into someone or cadre who is skillful in using guns but also to be led through exclusive doctrine which contains fairness, godliness, and justification claim so that they could become militant cadres who believe that what they do is not due to compulsion. However, they must believe that what they do is based on intention, determination, or spirit in order to become cadres who are always ready both as a member or as a leader of the organization in the future.

There is an explanation by Fahmi Maulana which stated that if a country wants to decrease or to defeat terrorism, the potential seedlings affected or taught to be the cadres of terrorism must be eradicated. ${ }^{1}$ Deconstructing pattern, system, or atmosphere which directs or releases someone to become a terrorist is one real and strategic step in balancing or responding its dynamic and progressiveness.

When some teenagers are found to justify exclusive paradigm which is shown through determining exclusive diversity option or spreading religion doctrine to other people, especially to someone or to people living in desperation or people becoming the victims of various unfairness, that religion doctrine understood and believed is considered the most truthful and guarantees them to heaven or is recognized in the aspect of vertical construction (hablumminallah), which must be fought for blood and lives, then they are actually trapped to become the cult of religion subjectivity, which actually has shaped them to be a terrorist identically.

In addition, though terrorists' movement is considered as left and subversive strength, with destructive pattern, which generates social, cultural, economic, and religious instability, which causes outrage and mass as well as massive suffering, they still believe that this radical-destructive movement is in line with religious orders or is still in the path of truth from "God's revelation".

If the particular condition takes place and develops, agency and education administrator's ideality must predict the movement paradigm constructed by the terrorists continuously. If the movement paradigm constructed is strongly maintained or is not shaken by any power (influence), like the power from the country or jurisprudence and religion doctrine from any beliefs, then objective and dynamic movement of terrorists could be an object of critical "learning".

In that aspect, ideality which could be used as a critical "learning" object is the terrorist's militant attitude in believing the righteousness of ideology and religion doctrine. They obey their leaders' orders, that these leaders are believed to be the source of righteousness of "revelation" or "God's hand" which must be followed absolutely, while these leaders are able to convince them that their management and leadership hold on to righteousness, fairness, honesty, and mandate.

\subsection{Implementation of Diversity Jurisprudence}

The success of policemen in dismantling the network is not automatically the success of weakening terrorism, or even shutting down cells of terrorism. Cells of terrorist comes from teenagers (youths) so it is not impossible that later they could create massive radical pattern because this type of society always look for problematic teenagers who could be utilized as instruments because training these teenagers is easy. Terrorism is one of many "community organizations" which is successful in transferring and implementing violence ideology and religion. Psychologically and psycho-logically, this radical ideology and religion is favored by problematic youth community. This is in line with the opinion from Cicero which stated that, "Ubi societas ibi ius" (where there is a society there is law) or where there is a society, there is crime. Crimes, including terrorists, are real products of society anomaly.

A number of terrorists who are dead already are namely Dr. Azahari, Nurdin M. Top, Dulmatin, Amrozi, etc. However, their deaths are not the end of the regenerating network. The success of terrorism in encompassing a number of problematic youths to be the cadres who could be predicted in their actions is a proof that terrorism has specific strategies to trap them.

In a book entitled Origins of Terrorism (Martha Crenshaw; Jerrold M Past: 2003), there are two factors which become the root of causes of terrorism in completing the actions. First, the cause of terrorism practice is the result of strategic choice. In this analysis, terrorism shows collective rationality. Thus, a particular radical political organization is considered the main role of terrorism drama. This factor generates a particular group which has main action choices and neglects other series of alternatives. Efficiency and effectiveness as well as cadres' reinforcement are the main standards in comparing towards other ways to reach the political purposes of terrorists. Second, terrorism performs the actions from the psycho-logic of terrorists that terrorists' behaviors are the result of psychology pressure. Terrorism carries out violence as an action caused by psychological encouragement. Their specific psycho-logic constructs the rationality of the actions which psychologically are

${ }^{1}$ Khalilul Umar, Op.Cit, pp.6. 
carried out forcefully. It means that individuals step into terrorism path are to take part in violent actions. ${ }^{1}$

Besides, there are several researches stated that problematic teenagers include teenagers dropping out of schools, teenagers living in a poor family, and teenagers trapped in delinquent habit. They are considered to be the element of society which is positioned as defeated community, which could be utilized by terrorist network. ${ }^{2}$

They could be trapped to be used as "machines" which are run and driven terrorism. They are not paid by money to step into the extraordinary crime but they are promised something bigger, more convincing, and more spiritually satisfying. Some which are taught to them are "it is more respectful to die by bombing in the name of ideology and fairness than to die wretchedly because of famine victims, lack of nutrition, or living in pain".

This is confirmed by Fadilah that terrorist regeneration in this country could only be predicted because they have well-organized and militant power, have strong ideology, are secretive, which from time to time struggles to prove the world that their organized network could never be defeated by anyone including security agencies (police and Indonesian National Army). They are obsessed to change the civilized world order according to their version and belief. ${ }^{3}$

It could be understood that terrorism is the description of organized crime which is fulfilled and maintained by highly intelligent people who are able to operate the organization as well as to transform its ideology in searching and seedling cadres.

They (terrorist leaders) not only recruit teenagers or college students to be the element of organization but also treat them as family members, pillar of congregation, or foundation of power, so that their obedience to the organization could exceed their obedience to their own family or even their religion. It is logical that there are families from the teenage terrorist who are surprised when they find out that their teenagers have become terrorists. They do not expect their silent and exclusive children have become parts of "terrorist family".

When this happens, what the country could do through education world is to work hard to close every root of criminogen which could result in the subject to be dragged, trapped, or affected by the power of terrorism network.

We are reminded by the Explanation of the Law of Republic of Indonesia Number 35 Year 2014 about Amendment to the Act Number 23 Year 2002 about Child Protection that children are inseparable parts from human survival and nation and country survivals. In order to be responsible in nation and country survivals, every child must obtain the widest opportunity to grow and thrive optimally in terms of physical, mental, and social. Therefore, attempts are needed to actualize children welfare by giving guarantees towards rights fulfillment indiscriminatingly.

The explanation also states that the country upholds human rights including rights of the child marked by the guarantee of protection and fulfillment of rights of the child in Indonesian Constitution 1945 and several provisions in regulation of law both nationally and internationally. This guarantee is strengthen by ratification of international convention about Rights of the Child which is the attestation of Rights of the Child Convention through Presidential Decree Number 36 Year 1990 regarding the attestation of Convention on the Rights of the Child.

It indicates that this country has bigger responsibility compared to family to close every root of criminogen which enables marginal condition of the learning subjects to be utilized by a group of terrorists. This country element must work hard to equalize objection-based or jihad-based education management towards the radical insight so that they will not be found by "a group of talent search" from the network of terrorism.

Kahlil Gibran has long reminded us regarding the other side of "the danger" of children when they are freely shaped by the society, as stated by his poem below:

Your children are not yours

They are the children of life who long for themselves

They were born through you but not from you

Though they are with you they do not belong to you

To them you can give your love, but not your mind

Because they have their own

You can lay off bodies but not their souls,

Because those souls live in the house of tomorrow which you can never visit even in a dream

You can be like them, but do not turn them into you

Because lives do not go backwards and are not in the past

You are arcs where your children become living arrows launched

The archer has aimed at the direction of eternity, and he stretches you with his strength so that the arrows can glide quickly and far

Turn the archer's hand into excitement

\footnotetext{
${ }^{1}$ Latif Sufyan, Terorisme: Kegagalan Psikologis Manusia, Kajian Keamnusiaan, dan Kebangsaan, 15 May 2017, pp.4.

${ }^{2}$ Ainul Chalid, dkk, Melacak Akar Penyebab Terorisme di Indonesia, LKPTI, Surabaya, 12 September 2015, pp.3.

${ }^{3}$ Haedar Mustofa, Op.Cit, pp.11.
} 
Because when he loves flying arrows, he also loves the bow he has launched with all his strength.

It is interesting to read the poem written by Ghibran because Ghibran wrote something about children not only from the side of the children but also from the side of us (family/society) which mostly shape them. Children were born from us but during their journey of life, they could be along with us or on the contrary they could choose the opposite direction.

We can and must provide them a way which according to us "the best way", but they uncertainly consider it as "the best way". We propose choices which according to us as "the most appropriate choice", but they uncertainly choose it or make it to be "the most appropriate choice". We could teach or "spoon-feed" them with righteousness, ideology, and heaven, but very necessarily they could decide paradoxically because of the influence of other power such as radical communities which are successful in shaping or dominating them.

The attempt of radical groups is to try to change the system of this country to be khalifah which is against the construction of the Unitary State of the Republic of Indonesia. There are several factors which influence teenagers regarding this which are heredity factor and recitation gatherings. However, the most trending factor is through the easily accessed social media. Many youths learn without teachers. They only read from the Internet whilst what they read is the type of radical teachings and is against the religious teachings. There are both positive and negative things in the Internet including how to make explosives. If those reading the radical teachings are youths who are short-minded in religion, it will be dangerous because it will affect their way of thinking. Young generation must be prepared for being anti-terrorism. ${ }^{1}$

We are at the area which is college (PT). Colleges have obligation to shape (educate) their students to be educational subjects who are not only intelligent in the scientific realm but also who have high nationalism, who understand, who are unshakable in attitudes and behaviors, who are state ideology-based people, which demand the students to be subjects who love unity in diversity.

Colleges are obligated to implement this in the curriculum and course subjects which are transformed into earthing activities especially in the students' scientific activities regarding jurisprudence which teaches diversity in life, society, and nation.

Diversity must also be learned from history that education is simply defined as a learning process which emphasizes on modesty. ${ }^{2}$ Moreover, needs of education have encouraged Indonesian Muslim society to adopt and transfer the existing religious and social institutions into Islamic education institutions in Indonesia. In Java, Muslims have adopted Hindu-Budha religious institutions to become boarding school (pesantren) educational institution. Minangkabau also takes over serau from being traditional relics to being Islamic education institution. It also happens in Aceh that they transfer maunasah institution to be Islamic education institution. ${ }^{3}$

For several things, what have been written by Ghibran could also be found in Imam Al-Ghazali's insights. According to Al-Ghazali, children are as precious as pearls who will always shine and "glow" brightly (righteousness) based on what they believe. They would always be the people who "glow" when they are inclined with truth, and they would lose their dazzling light if inclined to evil.

Ideally, colleges should implement education concept constructed by Al-Ghazali, that education process given in the early childhood must go through three phases namely: memorizing, understanding, and believing. A child, in Al-Ghazali's insight, is the manifestation of trust given from Allah to his parents. Therefore, if parents and even their teachers (at schools) bring them in the path of truth in the future, they will live happily ever after.

Al-Ghazali is one figure who are proposed to be the reference by religious learners and reviewers so that his insights on education, especially for children, could also be used as an option to establish his religious moral thinking. Children's minds, attitudes, and behaviors are shaped if they continuously are "influenced" or convinced that truth they accept is the truth which must be held on and upheld in life.

The basic and fundamental idea of Al-Ghazali lie on the process of students' personality formation. Children's personality are dominantly affected by the power shaping it. The power it inclines will make children's mind, psychology, attitudes, and behaviors shaped according to the power which influences (inflicts) it. When a child is able to perform attitude and behavior to love and protect each other in his life even though they have different religion, culture, politics, and ethnics, then he is successful in becoming a subject of learning who understands and implement jurisprudence (religion doctrine) of diversity. This attempt is not easy because Pancasila, which is the main umbrella of diversity doctrine, is also tested by a group of people or the children of nation in which they do not favor.

Pancasila is now faced with challenges from other ideology. Ideology which is brought by a group of radical Islam and a group of liberalism become a serious challenge. A group of radical Islam and liberal Islam struggle systematically to get rid of Pancasila from the system of economy, politics, and culture. There have been several proofs for this and among them is law which does not refer to the values of Pancasila anymore. ${ }^{4}$

\footnotetext{
${ }^{1} \mathrm{http}: / /$ nasional.tempo.co/read/news/2015/10/27/063713575/bnpt-cemas-banyak-anak-muda-indonesia-direkrut-jadi-teroris

${ }^{2}$ Pius A Partanto dan M. Dahlan Al Barry, Kamus Ilmiah Populer, (Surabaya: Arkola, 2001), pp.696.

${ }^{3}$ Harun Asrohan, Sejarah Pendidikan Islam, Cet. I; (Jakarta: PT Logos Wacana Ilmu, 1999), pp.144.

${ }^{4}$ Said Aqil Siradj dan Mamang Muhammad Haerudin, Berkah Islam Indonesia, Jalan Dakwah Rahmatan Lil'âlamîn, Quanta, Jakarta, 2015,
} 
This has also been stated by Mahfud MD that "the echo of Pancasila has slowly faded", 1 and one of social subjects which drives this is a group of radical people including college students.

Allah SWT's saying in Chapter An-Nisaa' verse 9 reminds that: “And let those executors and guardians fear injustice as if they themselves had left weak offspring behind and feared for them. So let them fear Allah and speak words of appropriate justice." This verse indirectly shows or delivers harsh critics that when a college student is trapped in being a terrorist, then this condition is the basic challenge for colleges to implement diversity education more seriously.

\section{Conclusion}

Indonesian society and the world have understood that terrorism is recognized as an extraordinary crime. The specialty of this crime is caused by the pattern of cadre recruitment or seedlings to stir the organization which is considered successful. In predicting the development and dynamics of this crime, there will always be young new cadres who are able to be invited to join it. What is performed by this terrorism is in comparison with "whatever broken will grow back, whatever lost will be replaced".

The development of terrorism and its activities cannot be let grow, even worse to be "tolerated" in the middle of society. There must be continuous attempts from many aspects to hinder or to prevent it. One of the attempts which might be undertaken by Muslims is to earthing the doctrine or jurisprudence of diversity. This doctrine has the substantial which is able to give effects towards the construction of understanding and attitudes of adherents of religion to be inclusive, democratic, and humanistic.

\section{References}

Books/Papers:

Ainul Chalid, dkk, Melacak Akar Penyebab Terorisme di Indonesia, LKPTI, Surabaya, 12 September 2015.

A.M. Hendroprioyono, Terorisme: Fundamentalis Kristen, Yahudi dan Islam, Buku Kompas, Jakarta, 2009

Eric Rosand, The Counter Terrorism Committee and the Fight Against Terrorism, American Journal International, 2003.

Harun Asrohan, Sejarah Pendidikan Islam, Cet. I, Jakarta: PT Logos Wacana Ilmu, 1999.

Haedar Mustofa, Dinamika Terorisme di Era Globalisasi, Lembaga Kajian Strategis Kebangsaan, 15 May 2016, Surabaya.

Khalilul Umar, Surat Dari teroris, LPPT-Indonesia-Global, Jakarta, 2012.

Latif Sufyan, Terorisme: Kegagalan Psikologis Manusia, Kajian Keamnusiaan, dan Kebangsaan, 15 May 2017.

Moh. Mahfud MD, Perdebatan Hukum Tata Negara Pasca Amandemen Konstitusi, LP3ES, Jakarta, 2007.

Nicholas Rostow, Before and After: The Changed UN Response to Terrorism Since September $11^{\text {th }}$, Cornel International Law Journal, 2002.

Pius A Partanto dan M. Dahlan Al Barry, Kamus Ilmiah Populer, Surabaya: Arkola, 2001

Prepared by the United Nations Office on Drugs and Crime, Legislative Guide To The Universal Anti-Terrorism Conventions And Protocols, United Nations, New York, 2004.

Romli Atmasasmita, dkk, State Terrorism dalam Perspektif Hukum, Hak Asasi Manusia, dan Agama, Lembaga Penerbitan Fakultas Hukum Unisma, 2003.

Said Aqil Siradj dan Mamang Muhammad Haerudin, Berkah Islam Indonesia, Jalan Dakwah Rahmatan Lil'âlamîn, Quanta, Jakarta, 2015

\section{Newspapers}

http://nasional.tempo.co/read/news/2015/10/27/063713575/bnpt-cemas-banyak-anak-muda-indonesia-direkrutjadi-teroris

\footnotetext{
hlm. 123

${ }^{1}$ Moh. Mahfud MD, Perdebatan Hukum Tata Negara Pasca Amandemen Konstitusi, LP3ES, Jakarta, 2007, hlm. 5.
} 